\title{
A Content Analysis of Published Articles in Journal of Anthropology of Sport and Physical Education from 2017 to 2018
}

\author{
Marin Corluka', Milica Bjelica² \\ ${ }^{1}$ University of Mostar, Faculty of Mathematics and Science Education, Mostar, Bosnia and Herzegovina, ${ }^{2}$ University of Ljubljana, Faculty of Economics, \\ Ljubljana, Slovenia
}

\begin{abstract}
Journal of Anthropology of Sport and Physical Education (JASPE) is a scientific journal that exists for two years and has so far released 87 scientific papers in 5 editions. The papers are from various fields of sports science - anthropology, sports marketing and other areas of sports. In this paper, we classified works by fields, method of address analysis and found that the most numerous works from the anthropology of sports, which are the most cited and best quoted in scientific databases. We have also established that the published works had themes - the most up-to-date tendencies in sports science. These research can be useful for further theoretical research, as well as for theoreticians. The authors of the works are researchers from all over the world, as well as the editorial board. The JASPE includes works from exact disciplines, primarily anthropology of sports, as well as from social sciences, thus achieving a synergistic effect.
\end{abstract}

Key words: Science, Journal, Anthropology, Sport, Physical Education

\section{Uvod}

Journal of Anthropology of Sport and Physical Education, časopis za antropologiju sporta i fizičkog vaspitanja (JASPE) je štampani i elektronski naučni časopis koji ima za cilj predstavljanje naučnih spoznaja stručnoj i naučnoj javnosti, uz korišćenje savremenih metoda. Od oktobra 2017. do danas objavljeno je pet izdanja časopisa. JASPE karakteriše: otvoreni pristup i slobodno dostupan online, brzo vrijeme objavljivanja, recenziranje od strane iskusnih naučnih istraživača, zajednički forum i komentarisanje članaka, medijsku pokrivenost u zemlji i svijetu, te vidljivost i uticaj u naučnim bazama samih radova, nakon objavljivanja.

JASPE izlazi četiri puta godišnje, $u$ januaru, aprilu, julu i oktobru svake godine, a objavljuje originalne naučne radove, pregledne članke, uvodnike, kratke izvještaje, recenziju - fer recenziju, kao i pozive i nagrade u oblasti antropologije sporta i fizičkog vaspitanja. Pokriva sve aspekte antropologije sporta i fizičkog obrazovanja iz pet glavnih oblasti antropologije: kulturne, globalne, biološke, jezičke i medicinske.

JASPE izdaje "Montenegrosport" u saradnji sa Fakultetom za sport i fiziko vaspitanje i sport Univerziteta Crne Gore i Crnogorskom sportskom akademijom. Glavni urednik je dr Bojan Mašanović sa Univerziteta Crne Gore, dok urednička mjesta po oblastima pokrivaju dr Miomir Maroš sa Univerziteta Crne Gore (kulturna antropologija), dr Kubilay Ocal sa Mugla univerziteta iz Turske (globalna antropologija), dr Dušan Stupar sa Educons univerziteta iz Srbije (fizička antropologija), dr Tatjana Jovović sa Univerziteta Crne Gore (lingvistička antropologija) i Nina Đukanović sa Univerziteta u Beogradu (medicinska antropologija).

U uređivački odbor časopisa izabrani su dr Fitim Arifi sa AAB College (Kosovo), dr Hassan Sedeghi sa Univerziteta Putra Malayisa (Malezija), dr Ivana Čerkez Zovko sa Univerziteta u Mostaru (Bosna i Hercegovina), dr Izet Bajramović sa Univerziteta u Sarajevu (Bosna i Hercegovina), dr Juel Jarani sa Univerziteta sporta u Tirani (Albanija), dr Luiz Fernando Rojo sa Univerziteta Federal Fluminense (Brazil), dr Marin Ćorluka sa Univerziteta u Mostaru (Bosna i Hercegovina), dr Radenko Matić sa Univerziteta u Novom Sadu (Srbija), dr Sami Sermaxhaj sa Universi College (Kosovo), dr Taher Afshar-

\section{Correspondence:}

\section{Montenegro}

Sport 
nezhad sa Shomal univerziteta (Iran) i dr Tonči Bavčević sa Sveučilišta u Splitu (Hrvatska).

Do sada je JASPE indeksiran u: DOAJ, Index Copernicus, Google Scholar, Crossref, Scientific Indexing Services, Genamics JournalSeek, ROAD, Cite Factor, Open Academic Journals Index, ISRA JIF, Universität Vechta, MIAR, J-Gate, Free medical journals, Caltech Library, REX - The Royal Library and Copenhagen University Library Service, Scilit, Pusan National University Library, Princeton University Library, Science Gate, University Library, Massey University Library, NDSL - National Digital Science Library, Mir@bel, Biblioteca Electrónica de Ciencia y Tecnología, Katalog Vědecké knihovny v Olomouci, Hochschulbibliothek Zittau/Görlitz, ExLibris,
EZB - Electroniche Zeitschriftenbibluothek, UTS - Library, Trova - National Library of Australia, WorldCat, BU Libraries Search, GIGA - German Institute of Global and Area Studies, UW - Madison Libraries i UB - Online Library. "U narednom periodu ćemo se potruditi da ga uvedemo u što veći broj indeksnih baza, kako bismo povećali vidljivost časopisa na međunarodnom planu, ali i prepoznatljivost i time privukli što veći broj referentnih autora iz oblasti antropologije sporta i fizičkog vaspitanja”, kazao je za sajt Univerziteta Crne Gore glavni urednik časopisa dr Bojan Mašanović i podsjetio da je pokrenuta procedura konstituisanja antropologije sporta kao samostalne discipline u okviru Svjetske antropološke asocijacije.

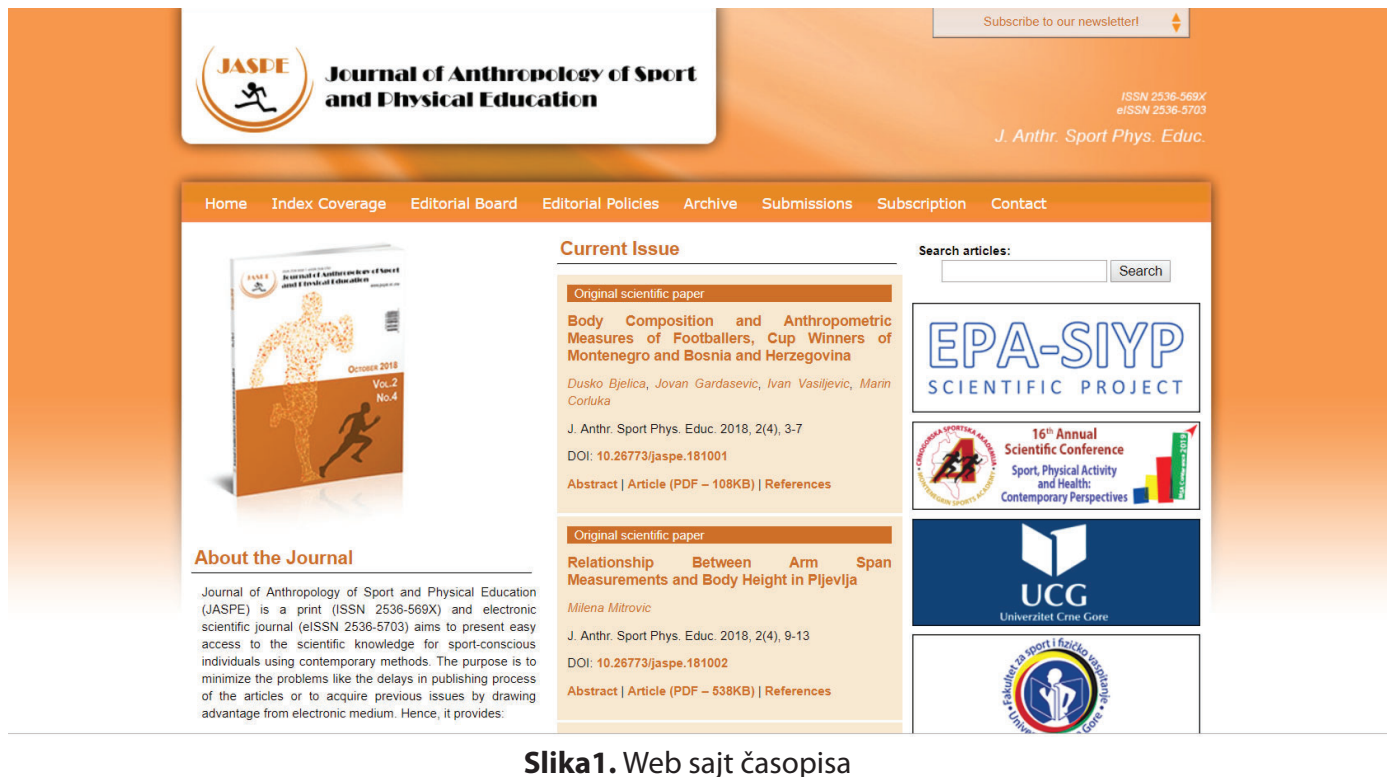

\section{Metod}

Analiza sadržaja je metoda često prisutna u medijskim istraživanjima koja kvalitativno i kvantitativno sistematizuje prvenstveno novinarske oblike komunikacije, pa se zbog otkrivanja frekvencija, odnosno učestalosti tema i poruka prilikom obrade podataka, koriste statističke metode, a u jednostavnijem obliku zbrajanje i deskripcija. Jedinica analize sadržaja u ovom radu su naslovi naučnih radova objavljenih u „Journal of Anthropology of Sport and Physical Education “, od oktobra 2017. do oktobra 2018. U tom periodu objavljeno je radova u 5 izdanja časopisa. Radovi su klasifikovani po oblastima sportskih nauka - na biomehaniku, fiziologiju, sportsku medicinu, antropologiju, metodologiju i ostale radove.

\section{Rezultati}

Antropologija sporta je prvenstvena oblast koju tangira ovaj časopis jer proučava veze između određenih disciplina i karakteristika sportista, a u JASPE je bila zastupljena kroz sljedeće radove: „Odnos između mjerenja raspona ruku i visine tijela u populaciji dinarskih Alpa: sistematski pregled (Masanovic, 2017)", "Razlike u morfološkim karakteristikama i tjelesnoj kompoziciji fudbalera u Crnoj Gori” (Corluka \& Vasiljevic, 2018), "Odnos između morfoloških karakteristika i dinamičkih parametara u slučaju dječaka dobi od 10-12 godina” (Likic, Bajramovic, \& Vranesic-Hadzimehmedovic, 2018), "Razlike u morfološkim karakteristikama i tjelesnom sastavu fudbalera FK Budućnost i FK Mladost u Crnoj Gori” (Gardasevic, Bjelica, Popovic, Vasiljevic \& Milosevic, 2018), "Razlike u morfološkim karakteristikama i tjelesnom sastavu fudbalera FK Sutjeska i FK Mladost u Crnoj Gori” (Bjelica, Gardasevic, \& Vasiljevic, 2018), "Razlike u morfološkim karakteristikama i tjelesnom sastavu rukometaša WHC Levalea i WHC Grude u Bosni i Hercegovini” (Vukotić, Corluka, Vasiljević, \& Bubanja, 2018), "Meta-analiza naučnih radova o efektima pripremnog perioda na osnovne motoričke vještine fudbalera kadeta" (Vasiljevic, 2017), “...na situacione motoričke sposobnosti fudbalera kadeta" (Vasiljevic, 2018), "Samoprijavljena i objektivno mjerena fizička aktivnost muškaraca od 50 do 69 godina" (Mitrovic, 2018), "Alometrijske varijacije savremenih ljudi i odnos između tjelesnih proporcija i elitnog atletskog uspjeha" (Monson, Brasil, \& Hlusko, 2018), "Uporedna studija morfoloških karakteristika i kompozicije tijela košarkaša iz Druge lige u Crnoj Gori i Srbiji" (Vukasevic, Vukotic, \& Masanovic, 2018), "Odnos mjerenja raspona ruku i visine tijela u Herceg Novom" (Dragutinovic, 2018), u Danilovgradu (Kovacevic, 2018), "Samoprijavljena i objektivno izmjerena tjelesna aktivnost starijih žena iz Bara i Podgorice" (Knezevic, 2018), "Uporedna studija antropometrijskog mjerenja i sastava tijela između prve i druge lige košarkaša u Crnoj Gori” (Vukasevic, Spaic, \& Masanovic, 2018), "Visina tijela i njena procjena korišćenjem mjerenja raspona ruku kod adolescenata iz sjevernog regiona u Crnoj Gori” (Bubanja, 2018), “...kod muških i ženskih adolescenata iz sjevernog regiona Crne Gore" (Vukotic, 2018), "Samoprijavljena i objektivno izmjerena tjelesna aktivnost starijih muškaraca iz Bara" (Kovacevic, 2018), "Razlike u morfološkim karakteristikama i tjelesnoj kompoziciji fudbalera FC Trepča 
'89 i FK Priština na Kosovu" (Gardasevic, Bjelica, Vasiljevic, Sermaxhaj, \& Arifi, 2018), "Odnos mjerenja raspona ruku i visine tijela u Baru" (Dragutinovic, 2018), "Visina tijela i njena procjena korišćenjem mjerenja raspona ruku kod muških i ženskih adolescenata iz Danilovgrada i Cetinja” (Vukotic, 2018), "Samoprijavljena i objektivno mjerena fizička aktivnost muškaraca od 50 do 69 godina" (Radulovic, 2018), "Razlike u morfološkim karakteristikama, brzini i aerobnoj izdržljivosti u odnosu na poziciju u timu najboljih ženskih fudbalera" (Bajramovic, Likic, Talovic, Alic, Jeleskovic, \& Sporis, 2018), "Odnos mjerenja raspona ruku i visine tijela u Bijelom Polju" (Knezevic, 2018), “...u Kolašinu” (Kovacevic, 2018), "Samoprijavljena i objektivno izmjerena tjelesna aktivnost starijih žena u Podgorici” (Dragutinovic, 2018), "Odnos mjerenja raspona ruku i visine tijela u Mojkovcu” (Knezevic, 2018), "Tjelesna kompozicija i antropometrijske mjere fudbalera, pobjednika kupova Crne Gore i Bosne i Hercegovine" (Bjelica, Gardasevic, Vasiljevic, \& Corluka, 2018), "Odnos mjerenja raspona ruku i visine tijela u Pljevljima” (Mitrovic, 2018), "Uporedna studija antropometrijskog mjerenja i tjelesne kompozicije između različitih nivoa takmičenja" (Masanovic, Spaic, \& Vukasevic, 2018), "Odnos mjerenja raspona ruku i visine tijela u Plavu" (Kovacevic, 2018), "Evaluacija nivoa tjelesne aktivnosti starijih žena u Kantonu Sarajevo u Bosni i Hercegovini” (Bajramovic, Bjelica, Talovic, Alic, \& Likic, 2018), "Profil specifične morfologije sporta: razlike $\mathrm{u}$ antropometrijskim karakteristikama između elitnih fudbalera i košarkaša" (Masanovic, Vukcevic, \& Spaic, 2018), "Visina tijela i njena procjena korišćenjem raspona adolescenata iz crnogorskih opština Berane i Pljevlja" (Bubanja, 2018), "Razlike antropometrijskih karakteristika tjelesne kompozicije ragbi igrača reprezentacije Crne Gore i Bugarske" (Malovic, 2018), "Odnos mjerenja raspona ruku i visine tijela u Beranama” (Mitrovic, 2018), "Razlike u antropometrijskim karakteristikama mladih juniora i košarkaša” (Spaic, Vukasevic, \& Masanovic, 2018), "Odnos mjerenja raspona ruku i visine tijela u Tivtu” (Radulovic \& Kovacevic, 2018), "Meta-analiza naučnih radova o efektima motoričkih vještina u košarci objavljenih u časopisu Sport Mont od 2006. do 2018." (Vasiljevic, 2018), "Uporedna studija morfoloških karakteristika i tjelesne kompozicije između elitnih košarkaša iz različitih regija" (Masanovic, Vukotic, \& Vukasevic, 2018) i "Meta-analiza naučnih radova o motoričkim vještinama u odbojci objavljenih u časopisu Sport Mont 2006-2016”. (Zoric, 2018).

Značajan i brojan je izbor radova iz Marketinga u sportu koji je nastao pojavom vrhunskog takmičarskog sporta, jer je ekonomski zanimljiv i može uticati na privredu u smislu povećane potrošnje i proizvodnje ili kao element turističke ponude. Radovi objavljeni u JASPE iz ove oblasti su: "Stavovi turskih potrošača prema oglašavanju u sportu u odnosu na učestalost gledanja sportskih događaja” (Masanovic, Zoric, \& Gardasevic, 2017), “...u odnosu na pitanje koliko često kupuju sportsku odjeću” (Zoric, Masanovic, \& Gardasevic, 2017), “...u odnosu na pitanje koliko često učestvuju u sportskim aktivnostima” (Gardasevic, Zoric, \& Masanovic, 2017), "Stavovi potrošača u Crnoj Gori prema reklamiranju u sportu u odnosu na učestalost gledanja sportskih događaja” (Masanovic, Zoric \& Gardasevic, 2018), “...u odnosu na pitanje koliko često učestvuju u sportskim aktivnostima” (Gardasevic, Zoric, \& Masanovic, 2018), “... u odnosu na pitanje koliko često kupuju sportsku odjeću” (Zoric, Masanovic, \& Gardasevic, 2018), "Stavovi potrošača u mostarskom kantonu u $\mathrm{BiH}$ prema oglašavanju u sportu u odnosu na pitanje koliko često kupuju sportsku odjeću” (Bjelica, Gardasevic \& Corluka, 2018), “...u odnosu na pitanje koliko često učestvuju u sportskim aktivnostima” (Corluka, Bjelica, \& Vukotic, 2018), “...u odnosu na učestalost gledanja sportskih događaja” (Vukotic, Corluka, \& Masanovic, 2018), "Stavovi potrošača u sarajevskom kantonu u $\mathrm{BiH}$ prema oglašavanju u sportu u odnosu na pitanje koliko često kupuju sportsku odjeću" (Zoric, Gardasevic, \& Bajramovic, 2018), “...u odnosu na pitanje koliko često učestvuju u sportskim aktivnostima” (Gardasevic, Bajramovic, \& Masanovic, 2018), “...u odnosu na učestalost gledanja sportskih događaja” (Bajramovic, Zoric, \& Masanovic, 2018). U toku ove godine, ovim istraživanjem obuhvaćeni su i građani glavnog grada $\mathrm{Cr}$ ne Gore: "Stavovi potrošača iz Podgorice prema oglašavanju u sportu u odnosu na pitanje koliko često kupuju sportsku odjeću” (Djurisic, Perovic, \& Masanovic, 2018), “...u odnosu na pitanje koliko često učestvuju u sportskim aktivnostima” (Kovacevic, Milosevic, \& Masanovic, 2018) i “...u odnosu na učestalost gledanja sportskih događaja” (Milovic, Corluka, \& Masanovic, 2018). Slična analiza je obuhvatila i gradove Autonomne pokrajine Vojvodine u Srbiji: "Stavovi potrošača sa Univerziteta u Novom Sadu prema reklamiranju u sportu u odnosu na učestalost gledanja sportskih događaja” (Molnar, Masanovic, \& Bjelica, 2018), “...u odnosu na pitanje koliko često učestvuju u sportskim aktivnostima” (Bjelica, Gusic, \& Maksimovic, 2018), “...u odnosu na to koliko često kupuju sportsku odjeću” (Milosevic, Bjelica, \& Matic, 2018), "Stavovi potrošača iz Subotice prema reklamiranju u sportu u odnosu na učestalost gledanja sportskih događaja" (Sekulic, Milosevic, \& Vukotic, 2018), “...u odnosu na pitanje koliko često učestvuju u sportskim aktivnostima” (Maksimovic, Sekulic, \& Corluka, 2018), "Stavovi potrošača iz Subotice prema reklamiranju u sportu u odnosu na pitanje koliko često kupuju sportsku odjeću” (Masanovic, Georgiev, \& Sekulic, 2018) i “Stavovi potrošača iz Autonomne Pokrajine Vojvodine prema reklamiranju u sportu u odnosu na pitanje koliko često učestvuju u sportskim aktivnostima" (Milosevic, Stupar, Molnar, \& Sekulic, 2018).

U istraživanju je učestvovala i akademska zajednica: "Stavovi potrošača sa Educons univerziteta prema reklamiranju u sportu u odnosu na učestalost gledanja sportskih događaja” (Stupar, Gardasevic, \& Masanovic, 2018), „...u odnosu na pitanje koliko često učestvuju u sportskim aktivnostima“ (Gardasevic, Stupar, \& Maksimovic, 2018) i „...u odnosu na pitanje koliko često kupuju sportsku odjeću“" (Milosevic, Vukotic, \& Stupar, 2018).

Iz Teorije sportskog treninga su radovi: "Meta-analiza naučnih radova iz oblasti sportskog treninga objavljenih u časopisu Sport Mont“ (Vukotic, 2018) i „Efekti četvoromjesečnog programa vježbanja na korekciju držanja tijela osoba sa različitim oštećenjima vida“ (Vranešić-Hadžimehmedović, Bajramović, Likić, Tabaković \& Imamović, 2018).

Iz oblasti fiziologije sporta je rad: "Fiziološki profil brazilskih elitnih fudbalera: poređenje između U-17, U-20 i profesionalaca" (Herdy, Costa, Simão, \& Selfe, 2018).

Iz oblasti dijagnostike je rad: "Odnos 2D:4D omjer i snaga rukohvata na učestalost multiple skleroze (Arazi, Olia, Nafissi, Moghadam, \& Falahati, 2018)".

Radovi koji se odnose na repulziju lopte su: "Repulzije lopte u stonom tenisu” (Bjelica, Vukotic, \& Gardasevic, 2018) i "Zavisnost repulzije teniske lopte od vazdušnog pritiska u njoj" (Bjelica, Bubanja, \& Gardasevic, 2018). 
Analizom do sada objavljenih radova i njihovom klasifikacijom bavili su se kroz sljedeće radove: „Analiza sadržaja objavljenih članaka u Crnogorskom časopisu za sportsku nauku i medicinu od 2012. do 2017.“ (Masanovic, 2017), „Analiza sadržaja objavljenih članaka u časopisu Sport Mont 2006.“ (Vukotic, 2018), „...u Sport Montu od 2016. do 2017.“ (Maros, 2018), „...u časopisu Sport Mont Journal 2004.“ (Mitrovic, 2018), „...u časopisu Sport Mont Journal 2004.“ (Dragutinovic, 2018), „...u časopisu Sport Mont Journal 2011.“ (Kovacevic, 2018), „Članci objavljeni u svim brojevima 2010. godine u Sport Mont Journal: Analiza sadržaja" (Knezevic, 2018), „Članci prof. Dr Duška Bjelica objavljeni u Sport Mont Journal: Analiza sadržaja“ (Vukovic, 2018), „Analiza sadržaja naučnih članaka objavljenih u časopisu Sport Mont Journal 2012.“ (Radulovic, 2018), „Meta-analiza originalnih naučnih radova u oblasti plivanja i vaterpola objavljeni u Sport Montu od 2003. do 2018.“ (Vukotic, 2018), „Članci o fudbalu objav- ljeni u Sport Montu od 2003. do 2018.“ (Maros, 2018), „Meta-analiza naučnih radova o efektima motoričkih vještina u košarci objavljenih u časopisu Sport Mont od 2006. do 2018.“ (Vasiljevic, 2018) i „Meta-analiza naučnih radova o motoričkim vještinama u odbojci objavljenih u časopisu Sport Mont 2006-2016.“ (Zoric, 2018).

Izvještaji sa konferencija su sastavni dio završnih djelova svakog časopisa, pa tako i JASPE, jer se njima dokumentuju važni događaji u naučnoj sportskoj zajednici, koji tako dobijaju više od aktuelnosti - arhiviranost. U dosadašnjem periodu to su bili: "Izveštaj sa 14. Međunarodne naučne konferencije o procesima transformacionim procesima u sportu „Sportske performanse "'” (Akpinar, 2017), "Izveštaj sa 5. Međunarodnog kongresa nutricionista" (Sekulic, 2018) i "Izveštaj sa 15. Međunarodne naučne konferencije o transformacionim procesima $\mathrm{u}$ sportu „Sportske performanse“” (Maros, 2018).

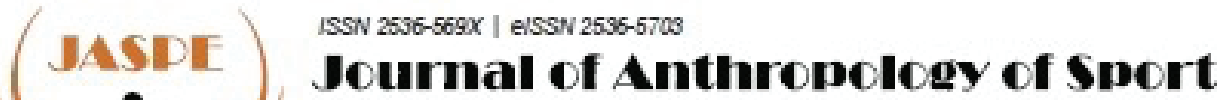 and Dhysical Education}

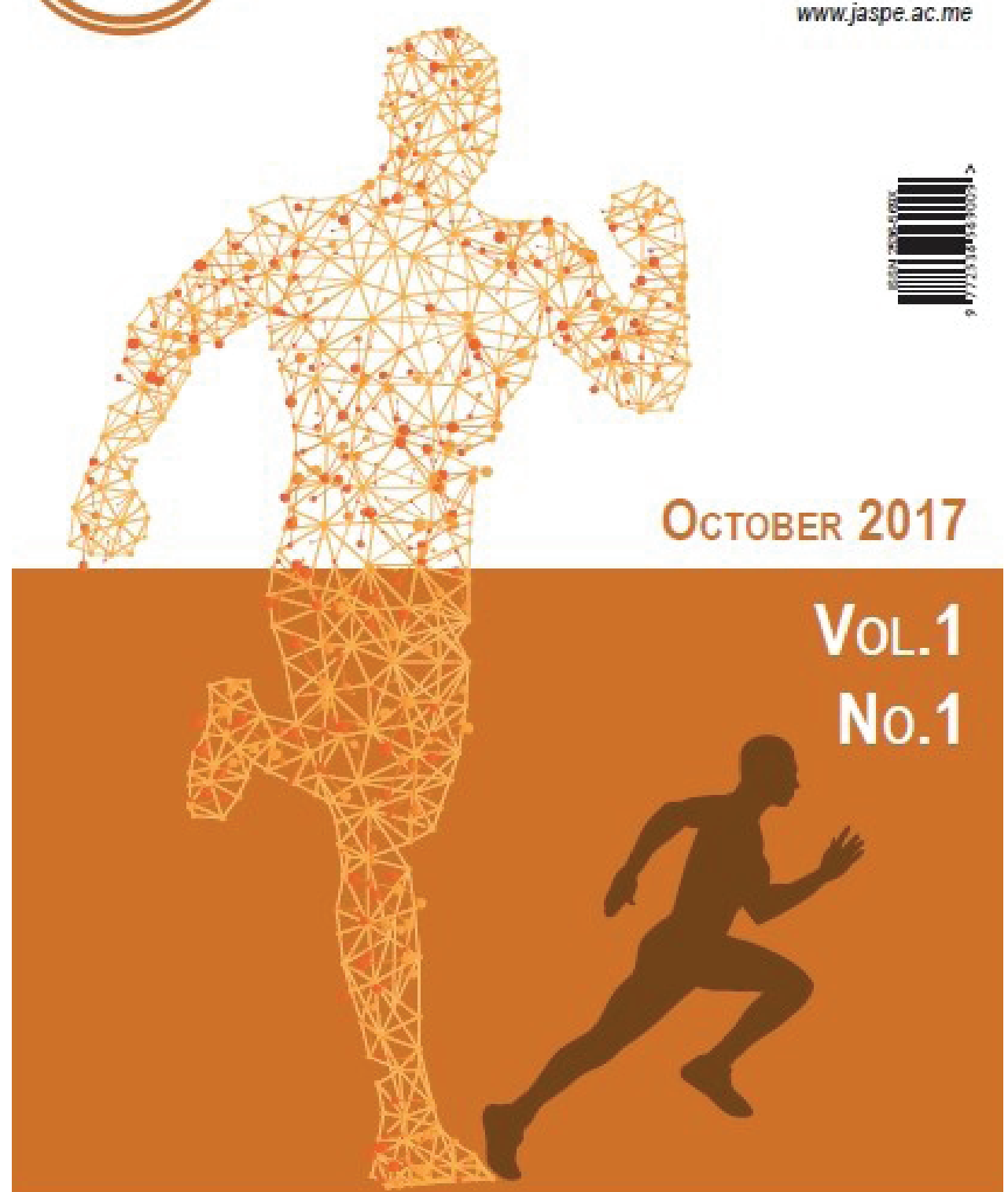

Slika 2. Naslovna strana časopisa 


\section{Diskusija}

U ovom radu smo klasifikovali teme iz JASPE-a po oblastima, kojih je bilo ukupno 87, a klasifikovali smo ih metodom analize naslova i utvrdili da su najbrojniji radovi iz antropologije sporta (39), marketinga u sportu (25), te da su prisutni radovi iz fiziologije i dijagnostike, kao i teorije sportskog treninga, kao i analiza sadržaja i izvještaji sa konferencija. Radovi iz antropologije sporta, pogotovo oni koji se odnose na antropometrijska mjerenja sportista su najcitiraniji i najbolje kotirani, pa je to i razlog napredovanja časopisa u smjeru viših naučnih baza u sportskim naukama. Utvrdili smo i da su objavljeni radovi imali za teme - najsavremenije tendencije u sportskim naukama. Ta istraživanja mogu biti korisna i za dalja teorijska istraživanja, kao i za sportske praktičare.

\section{Acknowledgements}

There are no acknowledgements.

\section{Conflict of Interest}

The authors declare that there are no conflicts of interest.

Received: 22 November 2018 | Accepted: 27 December 2018 | Published: 25 January 2019

\section{References}

Akpinar, S. (2017). Report of the 14th International Scientific Conference on Transformation Processes in Sport "Sports Performance". Journal of Anthropology of Sport and Physical Education, 1(1), 39-42.

Arazi, H., Olia, R.B.B., Nafissi, S., Moghadam, N.B., \& Falahati, A. (2018). The Relationship of 2D:4D Ratio and Hand Grip Strength to the Incidence of Multiple Sclerosis. Journal of Anthropology of Sport and Physical Education, 2(3), 85-91.

Bajramovic, I., Bjelica, D., Talovic, M., Alic, H., \& Likic, S. (2018). Evaluation of the Physical Activity Level of Elderly Women in the Canton of Sarajevo in Bosnia and Herzegovina. Journal of Anthropology of Sport and Physical Education, 2(3), 33-36.

Bajramovic, I., Likic, S., Talovic, M., Alic, H., Jeleskovic, E., \& Sporis, G. (2018) Differences in the Level of Morphological Characteristics, Speed Abilities and Aerobic Endurance in Relation to the Team Position of Top Female Football Players. Journal of Anthropology of Sport and Physical Education, 2(3), 127-130.

Bajramovic, I., Zoric, G., \& Masanovic, B. (2018). Attitudes of Consumers from the Sarajevo Canton in Bosnia and Herzegovina toward Advertising through Sport among the Frequency of Watching Sports Events. Journal of Anthropology of Sport and Physical Education, 2(2), 43-47.

Bjelica, B., Vukotic, M., \& Gardasevic, J. (2018). Repulsions Ball in Table Tennis. Journal of Anthropology of Sport and Physical Education, 2(3), 15-19.

Bjelica, D., Bubanja, M., \& Gardasevic, J. (2018). The Dependence of Repulsion Tennis Ball from the Air Pressure in it. Journal of Anthropology of Sport and Physical Education, 2(3), 77-82.

Bjelica, D., Gardasevic, J., \& Corluka, M. (2018). Attitudes of Consumers from the Mostar Canton in Bosnia and Herzegovina toward Advertising through Sport among the Question how often Consumers purchase Sporting Goods. Journal of Anthropology of Sport and Physical Education, 2(2), 3-7.

Bjelica, D., Gardasevic, J., \& Vasiljevic, I. (2018). Differences in the Morphological Characteristics and Body Composition of Football Players FC Sutjes$\mathrm{ka}$ and FC Mladost in Montenegro. Journal of Anthropology of Sport and Physical Education, 2(2), 31-35.

Bjelica, D., Gardasevic, J., Vasiljevic, I., \& Corluka, M. (2018). Body Composition and Anthropometric Measures of Footballers, Cup Winners of Montenegro and Bosnia and Herzegovina. Journal of Anthropology of Sport and Physical Education, 2(3), 3-7.

Bjelica, D., Gusic, M., \& Maksimovic, N. (2018). Attitudes of Consumers from University of Novi Sad toward Advertising through Sport among the Question how Often they Participate in Sports Activities. Journal of Anthropology of Sport and Physical Education, 2(3), 15-20.

Bubanja, M. (2018). Body Height and Its Assessment by Using the Arm Span of Adolescents From the Montenegrin Municipalities of Berane and Pljevlja. Journal of Anthropology of Sport and Physical Education, 2(3), 49-53.

Bubanja, M. (2018). Body Height and Its Estimation Utilizing Arm Span Measurements in Adolescents From Northern Region in Montenegro. Journal of Anthropology of Sport and Physical Education, 2(3), 67-71.
Corluka, M., \& Vasiljevic, I. (2018). Differences in the Morphological Characteristics and Body Composition of Football Players in Montenegro. Journal of Anthropology of Sport and Physical Education, 2(1), 3-7.

Corluka, M., Bjelica, D., \& Vukotic, M. (2018). Attitudes of Consumers from the Mostar Canton in Bosnia and Herzegovina toward Advertising through Sport among the Question how Often they Participate in Sports Activities. Journal of Anthropology of Sport and Physical Education, 2(2), 9-13.

Djurisic, V., Perovic, Dj., \& Masanovic, B. (2018). Attitudes of Consumers from Podgorica toward Advertising through Sport among the Question how often Consumers purchase Sporting Goods. Journal of Anthropology of Sport and Physical Education, 2(2), 55-60.

Dragutinovic, K. (2018). Content Analyses of Scientific Articles from All Issues Published in Sport Mont Journal in 2009. Journal of Anthropology of Sport and Physical Education, 2(2), 83-87.

Dragutinovic, K. (2018). Relationship Between Arm Span Measurements and Body Height in Herceg Novi. Journal of Anthropology of Sport and Physical Education, 2(3), 27-32.

Dragutinovic, K. (2018). Relationship Between Arm Span Measurements and Body Height in Bar. Journal of Anthropology of Sport and Physical Education, 2(3), 111-115.

Dragutinovic, K. (2018). Self-Reported and Objectively Measured Physical Activity of Elderly Women in Podgorica. Journal of Anthropology of Sport and Physical Education, 2(3), 155-158.

Gardasevic, J., Bajramovic, I., \& Masanovic, B. (2018). Attitudes of Consumers from the Sarajevo Canton in Bosnia and Herzegovina toward Advertising through Sport among the Question how Often they Participate in Sports Activities. Journal of Anthropology of Sport and Physical Education, 2(2), 37-41.

Gardasevic, J., Bjelica, D., Popovic, S., Vasiljevic, I., \& Milosevic, Z. (2018). Differences in the Morphological Characteristics and Body Composition of Football Players FC Buducnost and FC Mladost in Montenegro. Journal of Anthropology of Sport and Physical Education, 2(1), 51-55

Gardasevic, J., Bjelica, D., Vasiljevic, I., Sermaxhaj, S., \& Arifi, F. (2018). Differences in the Morphological Characteristics and Body Composition of Football Players FC Trepca '89 and FC Prishtina in Kosovo. Journal of Anthropology of Sport and Physical Education, 2(3), 105-109.

Gardasevic, J., Stupar, D., \& Maksimovic, N. (2018). Attitudes of Consumers from Educons University toward Advertising through Sport among the Question how Often they Participate in Sports Activities. Journal of Anthropology of Sport and Physical Education, 2(3), 137-142.

Gardasevic, J., Zoric, G., \& Masanovic, B. (2017). Attitudes of Turkish Consumers toward Advertising through Sport among the Question how often they participate in Sports Activities. Journal of Anthropology of Sport and Physical Education, 1(1), 23-27.

Gardasevic, J., Zoric, G., \& Masanovic, B. (2018). Attitudes of Montenegrin Consumers Toward Advertising Through Sport Among the Question How Often They Participate in Sports Activities. Journal of Anthropology of Sport and Physical Education, 2(1), 15-19.

Herdy, H., Costa, P.B., Simão, R., \& Selfe, J. (2018). Physiological Profile of Brazilian Elite Soccer Players: Comparison between U-17, U-20 and professionals. Journal of Anthropology of Sport and Physical Education, 2(3), 43-47.

Knezevic, M. (2018). Articles Published in all issues in 2010 in Sport Mont Journal: A Content Analysis. Journal of Anthropology of Sport and Physical Education, 2(2), 103-108.

Knezevic, M. (2018). Relationship Between Arm Span Measurements And Body Height in Bijelo Polje. Journal of Anthropology of Sport and Physical Education, 2(3), 143-147.

Knezevic, M. (2018). Relationship Between Arm Span Measurements And Body Height In Mojkovac. Journal of Anthropology of Sport and Physical Education, 2(3), 165-169.

Knezevic, M. (2018). Self-Reported and Objectively Measured Physical Activity of Elderly Womens From Bar and Podgorica. Journal of Anthropology of Sport and Physical Education, 2(3), 39-42.

Kovacevic, D., Milosevic, Z., \& Masanovic, B. (2018). Attitudes of Consumers from Podgorica toward Advertising through Sport among the Question how Often they Participate in Sports Activities. Journal of Anthropology of Sport and Physical Education, 2(2), 61-65.

Kovacevic, M., \& Radulovic, J. (2018). Relationship Between Arm Span Measurements and Body Height in Plav. Journal of Anthropology of Sport and Physical Education, 2(3), 27-31.

Kovacevic, M. (2018). Content Analyses of Scientific Articles from Issues Published in Sport Mont Journal in 2011. Journal of Anthropology of Sport and Physical Education, 2(2), 89-98.

Kovacevic, M. (2018). Relationship between Arm Span Measurements and Body Height in Danilovgrad. Journal of Anthropology of Sport and Physical Education, 2(3), 33-37. 
Kovacevic, M. (2018). Relationship between Arm Span Measurements and Body Height in Kolasin. Journal of Anthropology of Sport and Physical Education, 2(3), 149-153.

Kovacevic, M. (2018). Self-Reported and Objectively Measured Physical Activity of Elderly Mans from Bar. Journal of Anthropology of Sport and Physical Education, 2(3), 79-83.

Likic, S., Bajramovic, I., \& Vranesic-Hadzimehmedovic, D. (2018). Relationship Between Morphological Characteristics and Dynamic Running Parameters in the Case of Boys Aged 10-12 years. Journal of Anthropology of Sport and Physical Education, 2(1), 27-30.

Maksimovic, N., Sekulic, N., \& Corluka, M. (2018). Attitudes of Consumers from Subotica toward Advertising through Sport among the Question how often they Participate in Sports Activities. Journal of Anthropology of Sport and Physical Education, 2(3), 93-98.

Malovic, P. (2018). Differences in Anthropometric Characteristics and Body Composition between Rugby Players of National Team of Montenegro and National Team of Bulgaria. Journal of Anthropology of Sport and Physical Education, 2(3), 65-69.

Maros, M. (2017). A Content Analysis of Published Articles in Montenegrin Journal of Sports Science and Medicine from 2012 to 2017. Journal of Anthropology of Sport and Physical Education, 1(1), 9-15.

Maros, M. (2018). A Content Analysis of Published Articles in Sport Mont from 2016 to 2017. Journal of Anthropology of Sport and Physical Education, 2(1), 41- 46

Maros, M. (2018). Articles of football published in Sport Mont from 2003 to 2018. Journal of Anthropology of Sport and Physical Education, 2(3), 8388.

Maros, M. (2018). Report of the 15th International Scientific Conference on Transformation Processes in Sport "Sports Performance". Journal of Anthropology of Sport and Physical Education, 2(3), 171-173.

Masanovic, B. (2017). Relationship between Arm Span Measurements and Body Height in Dinaric Alpes Population: a Systematic Review. Journal of Anthropology of Sport and Physical Education, 1(1), 33-37.

Masanovic, B., Georgiev, G., \& Sekulic, N. (2018). Attitudes of Consumers from Subotica toward Advertising through Sport among the Question how often Consumers purchase Sporting Goods. Journal of Anthropology of Sport and Physical Education, 2(3), 99-104.

Masanovic, B., Spaic, S., \& Vukasevic, V. (2018). Comparative Study of Anthropometric Measurement and Body Composition between Different Levels of Competition. Journal of Anthropology of Sport and Physical Education, 2(3), 21-26.

Masanovic, B., Vukcevic, A. \& Spaic, S. (2018). Sport-Specific Morphology Profile: Diff erences in Anthropometric Characteristics between Elite Socce and Basketball Players. Journal of Anthropology of Sport and Physical Education, 2(3), 43-47.

Masanovic, B., Vukotic, M., \& Vukasevic, V. (2018). Comparative Study of Morphological Characteristics and Body Composition between Elite Basketball Players from Different Regions. Journal of Anthropology of Sport and Physical Education, 2(3), 103-107.

Masanovic, B., Zoric, G., \& Gardasevic, J. (2017). Attitudes of Turkish Consumers toward Advertising through Sport among the Frequency of Watching Sports Events. Journal of Anthropology of Sport and Physical Education, 1(1), 3-7.

Masanovic, B., Zoric, G., \& Gardasevic, J. (2018). Attitudes of Montenegrin Consumers Toward Advertising Through Sport Among the Frequency of Watching Sports Events. Journal of Anthropology of Sport and Physical Education, 2(1), 9-13.

Milosevic, Z., Bjelica, D., \& Matic, R. (2018). Attitudes of Consumers from University of Novi Sad toward Advertising through Sport among the Question how oft en Consumers purchase Sporting Goods. Journal of Anthropology of Sport and Physical Education, 2(3), 49-54.

Milosevic, Z., Stupar, D., Molnar, S., \& Sekulic, N. (2018). Attitudes of Consumers from Autonomus Province of Vojvodina toward Advertising through Sport among the Question how Often they Participate in Sports Activities. Journal of Anthropology of Sport and Physical Education, 2(3), 55-60.

Milosevic, Z., Vukotic, M., \& Stupar, D. (2018). Attitudes of Consumers from Educons University toward Advertising through Sport among the Question how oft en Consumers purchase Sporting Goods. Journal of Anthropology of Sport and Physical Education, 2(3), 159-164.

Milovic, N., Corluka, M., \& Masanovic, B. (2018). Attitudes of Consumers from Podgorica toward Advertising through Sport among the Frequency of Watching Sports Events. Journal of Anthropology of Sport and Physical Education, 2(2), 71-76.

Mitrovic, M. (2018). Content Analyses of Scientific Articles from Issues Published in Sport Mont Journal in 2004. Journal of Anthropology of Sport and Physical Education, 2(2), 77-81.
Mitrovic, M. (2018). Relationship Between Arm Span Measurements and Body Height in Pljevlja. Journal of Anthropology of Sport and Physical Education, 2(3), 9-13.

Mitrovic, M. (2018). Relationship Between Arm Span Measurements and Body Height in Berane. Journal of Anthropology of Sport and Physical Education, 2(3), 71-75.

Mitrovic, M. (2018). Self-Reported and Objectively Measured Physical Activity of Males from 50 to 69 Years Old. Journal of Anthropology of Sport and Physical Education, 2(2), 99-101.

Molnar, S., Masanovic, B., \& Bjelica, D. (2018). Attitudes of Consumers from University of Novi Sad toward Advertising through Sport among the Frequency of Watching Sports Events. Journal of Anthropology of Sport and Physical Education, 2(3), 9-14.

Monson, T.A., Brasil, M.F., \& Hlusko, L.J. (2018). Allometric Variation in Modern Humans and the Relationship Between Body Proportions and Elite Athletic Success. Journal of Anthropology of Sport and Physical Education, 2(3), 3-8.

Radulovic, J. (2018). Content Analyses of Scientific Articles from Issues Published in Sport Mont Journal in 2012. Journal of Anthropology of Sport and Physical Education, 2(2),115-120.

Radulovic, J. \& Kovacevic, M. (2018). Relationship Between Arm Span Measurements and Body Height in Tivat. Journal of Anthropology of Sport and Physical Education, 2(3), 93-97.

Radulovic, J. (2018). Self-Reported and Objectively Measured Physical Activity of Males from 50 to 69 Years Old. Journal of Anthropology of Sport and Physical Education, 2(3), 123-126.

Sekulic, N. (2018). Report of the 5th International Congress of Nutritionists. Journal of Anthropology of Sport and Physical Education, 2(1), 57- 60.

Sekulic, N., Milosevic, Z., \& Vukotic, M. (2018). Attitudes of Consumers from Subotica toward Advertising through Sport among the Frequency of Watching Sports Events. Journal of Anthropology of Sport and Physical Education, 2(3), 55-60.

Spaic, S., Vukasevic, V., \& Masanovic, B. (2018). Differences in Anthropometric Characteristics among Junior Soccer and Basketball Players. Journal of Anthropology of Sport and Physical Education, 2(3), 89-92.

Stupar, D., Gardasevic, J., \& Masanovic, B. (2018). Attitudes of Consumers from Educons University toward Advertising through Sport among the Frequency of Watching Sports Events. Journal of Anthropology of Sport and Physical Education, 2(3), 131-136.

Vasiljevic, I. (2017). Meta-Analyze of the Scientific Papers on the Effects of the Preparation Period on the Basic Motor Skills of the Cadet Football Players. Journal of Anthropology of Sport and Physical Education, 1(1), 29-32.

Vasiljevic, I. (2018). Meta-Analyze of the Scientific Papers on the Effects of the Preparation Period on the Situational Motor Skills of the Cadet Football Players. Journal of Anthropology of Sport and Physical Education, 2(2), 67-70.

Vasiljevic, I. (2018). Meta-Analysis of Scientific Papers on effects of Motor Skills in the Basketball Published in the Journal Sport Mont from 2006 to 2018. Journal of Anthropology of Sport and Physical Education, 2(3), 99-101.

Vranešić-Hadžimehmedović, D., Bajramović, l., Likić, S., Tabaković, M., \& Imamović, Dž. (2018). Effects of Four-Month Exercise Program on Correction of Body Posture of Persons with Different Visual Impairment. Journal of Anthropology of Sport and Physical Education, 2(2), 15-18.

Vukasevic, V., Spaic, S., \& Masanovic, B. (2018). Comparative Study of Anthropometric Measurement and Body Composition between the Basketball Player First and Second League in Montenegro. Journal of Anthropology of Sport and Physical Education, 2(3), 61-65.

Vukasevic, V., Vukotic, M., \& Masanovic, B. (2018). Comparative Study of Morphological Characteristics and Body Composition between Basketball Players from Second Leagues in Montenegro and Serbia. Journal of Anthropology of Sport and Physical Education, 2(3), 21-25.

Vukotic, M. (2018). Analysis of the Content of Published Articles in the Journal Sport Mont 2006. Journal of Anthropology of Sport and Physical Education, 2(1), 31-39

Vukotic, M. (2018). Body Height and its Estimation Utilizing Arm Span Measurements in Male and Female Adolescents from Northern Region in Montenegro. Journal of Anthropology of Sport and Physical Education, 2(3), 73-77.

Vukotic, M. (2018). Body Height and its Estimation Utilizing Arm Span Measurements in Male and Female Adolescents from Danilovgrad and Cetinje. Journal of Anthropology of Sport and Physical Education, 2(3), 117121.

Vukotic, M. (2018). Meta-Analysis of Scientific Papers in the Field of Sports Training Published in the Journal Sport Mont 2016. Journal of Anthropology of Sport and Physical Education, 2(1), 47- 49. 
Vukotic, M. (2018). Meta-Analysis Orginal Scientific Papers in the Field of Swimming and Water polo Published in Sport Mont from 2003 to 2018. Journal of Anthropology of Sport and Physical Education, 2(3), 61-64.

Vukotic, M. (2018). The importance of physical activity and fitness programs in older people: a Systemic review. Journal of Anthropology of Sport and Physical Education, 2(3), 37-41.

Vukotic, M., Corluka, M., \& Masanovic, B. (2018). Attitudes of Consumers from the Mostar Canton in Bosnia and Herzegovina toward Advertising through Sport among the Frequency of Watching Sports Events. Journal of Anthropology of Sport and Physical Education, 2(2),19-23.

Vukotić, M., Corluka, M., Vasiljević, I., \& Bubanja, M. (2018). Differences in the Morphological Characteristics and Body Composition of Handball Players WHC Levalea in Montenegro and WHC Grude in Bosnia and Herzegovina. Journal of Anthropology of Sport and Physical Education, 2(2), 49-53.

Vukovic, I. (2018). Prof. Dr. Dusko Bjelica's Articles Published in Sport Mont Journal: A Content Analysis. Journal of Anthropology of Sport and Physical Education, 2(2), 109-113.
Zoric, G. (2018). Meta-Analysis of Scientific Papers in the Field of Motor Skills from Volleyball Published in the Journal Sport Mont 2006-2016. Journal of Anthropology of Sport and Physical Education, 2(3), 109-112.

Zoric, G. Gardasevic, J., \& Bajramovic, I. (2018). Attitudes of Consumers from the Sarajevo Canton in Bosnia and Herzegovina toward Advertising through Sport among the Question how often Consumers purchase Sporting Goods. Journal of Anthropology of Sport and Physical Education, 2(2), 25-29.

Zoric, G., Masanovic, B., \& Gardasevic J. (2017). Attitudes of Turkish Consumers toward Advertising through Sport among the Question how often Consumers purchase Sporting Goods. Journal of Anthropology of Sport and Physical Education, 1(1), 17-21.

Zoric, G., Masanovic, B., \& Gardasevic J. (2018). Attitudes of Montenegrin Consumers Toward Advertising Through Sport Among the Question How Often Consumers Purchase Sporting Goods. Journal of Anthropology of Sport and Physical Education, 2(1), 21-25. 